\title{
Overview Of Gender Victims Of Family In The Household In Garut District
}

\author{
Hanifah' ${ }^{1}$, Rafiudin'2, Fathimah Madaniyyah ${ }^{3}$, Supiana ${ }^{4}$ \\ 1STAIDA Muhammadiyyah Garut \\ 2Sekolah Tinggi Ilmu Komputer Cilegon \\ 3STAI Darul Arqam Muhammadiyah Garut \\ 4UIN Sunan Gunung Djati Bandung \\ * Corresponding author E-mail: Hanifah6886@gmail.com
}

\begin{abstract}
Data from the West Java Women's and Child Empowerment (P2TP2A) Integrated Service Center counselor, shows that the number of domestic violence (KDRT) in West Java is still high. In one year P2TP2A can handle more than 100 cases. that number could be more because until now there are still many victims of domestic violence who do not dare to report. This is a concern of the community and the regional government of West Java, so the problem is how to protect victims of domestic violence in Garut This writing study uses literature studies that emphasize data collection through searching / reviewing books related to research. The data analysis method used is a descriptive-analytical method bycollecting and compiling data, then analysis and interpretation of the data are sought. Violence against women and children victims of domestic violence in Garut Regency over the past five years as many as 430 cases including 2014 violence against women, 46 cases, in 2015 there were 31 cases, in 2016 there were 37 cases, in 2017 there were 30 cases and in 2018 as many as 17 cases. This shows that the amount of violence against women has decreased from year to year. Garut Regency protects women and children who are victims of violence by fulfilling the rights of women and child ren victims of violence and discrimination starting from prevention efforts, social services, and rehabilitation. All protection aims to protect women and provide security in the fulfillment of their rights by providing consistent and systematic attention aimed at achieving gender equality.
\end{abstract}

Keywords: Victims of Domestic Violence, Gender Review

\section{INTRODUCTION}

Every family wants to build a happy and loving family, both physically and mentally, in other words, that every family wants to beable to build a family of harmony and happiness that is often called the sacred family, mawaddah was rahmah (Wahab, 2006). West Java Women's and Children Empowerment (P2TP2A) Integrated Service Center Counselor, Rita Sukendar, said the number of domestic violence (KDRT) in West Java is still high. In one year P2TP2A can handle more than 100 cases. According to Rita, the number could be more, because until now there are still many victims of domestic violence who do not dare to report (Tribun Jabar, Domestic Violence Rate in WestJava, April 23,2016).

Households should be a place that provides peace (sakinah) for everyone (Wahab 2006), Violence in the household, occurs within the scope of the family, even though the family is an ideal social institution to grow and develop the potential that exists in each individual (Wahid, 2018) the family is often a container for the emergence of various cases of irregularities in other illegal activities that cause misery or suffering, which is carried out by one family member against other family members, such as persecution, rape, murder. This situation is commonly referred to as domestic violence (Nainggolan, Zahara, \& Saparuddin, 2010).

\footnotetext{
* Copyright (c) 2020 Hanifah et.all
}

This work is licensed under a Creative Commons Attribution-ShareAlike 4.0 International License. 
Several previous studies had been discussed by Jamaa (2014). He examined the Protection of Victims of Domestic Violence in Indonesian Criminal Law which resulted in the form of protection of victims of domestic violence still dominant through repressive measures, also examined by Sholihat (2018)) about the confirmation of four factors that affect empowerment of women victims of domestic violence produces the role of health workers that most influences the empowerment of women victims of violence and by Ikrom (2013)) on Islamic Sharia in the Perspective of Gender and Human Rights (HAM) with the results of roles and responsibilities of women at the level of men. Both are equally God's creation, both humans, are equallypotential to be the caliph of fi al-ardh and also equally potential to be the facade of fi al-ardh. This study looks more into violence that occurs in households that have a focus on gender and is carried out in Garut Regency to find ways to reduce acts of violence in the household.

The social support received by victims of domestic violence can vary from person to person. High social supporthelpswomen victims of violence to be able to choose strategies to deal with problems that are effective in dealing with domestic violence. Meanwhile, when social support is not obtained bywomen victims of domestic violence, they lack information that can be used to assess the problem of violence they experienced logically or plan constructive solutions.

\section{RESEARCHMETHOD}

This writing study uses the study of literature. According to Burhan Bungin "The literacy method is one of the data collection methods used in social research methods to trace historical data (Bungin, 2007). This means that the study of literature is a study that emphasizes the collection of data through searching / reviewing books related to research,in thiscase, the study of literature isfocused on the study of relevant social books. The data analysis method used is the descriptive-analytical method. The descriptiveanalytical method is an attempt to collect and compile data, then analysis and interpretation of data are arranged (Surakhmad, 1982) In other words, the descriptive-analytical method focuses on research problems, so the research results are then processed and analyzed to conclude (Sugiyono, 2013)..

\section{RESULTS AND DISCUSSION}

The issue of female violence in households in Indonesia is still considered normal and considers it a dynamic of life that must be lived. So many household women do not dare to report the violence they experienced because they thought it wasa disgrace in the family that no one else should know about. The phenomenon of violence is like an iceberg. This means that the cases revealed (public) are only a small part of the forms of violence against women in the household that have not been exposed to the surface. Of course, this is the duty of all parties thatall forms of violence mustbe eliminated, especially on women. As for the forms of domestic violence, namely: (Forms of domestic violence according to Article 5 of RI Law No. 23 of 2004).

1. Physical violence, which is an act that causespain, falls ill or is seriously injured (Ps 5 jo 6). Physical violence can be exemplified such askicking, slapping, hitting, cr ushing, biting and so on. Actions that cause pain must naturally get medical treatment according to the violence they experienced.

2. b. Psychicviolence, which is actionsthat result in fear, loss of self-confidence, loss of ability to act, feelings of helplessness, and / or severe psychological sufferingin a person (Ps 5 jo 7). It can be exemplified as threatening behavior, intimidating, berating / insulting, bullying, and so forth. This psychological violence if itoccurs in children will certainly have 
an impact on children's development and psychological, so it tends to experience prolonged trauma. This can also occur in women.

3. c. Sexual Violence, i.e. every act in the form of forced sexual relations, forced sexual relations in an unnatural and / or undesirable manner, forced sexual relations with other people for commercial purposes and / or specific purposes (Ps 5 jo 8), which include: (a) the imposition of sexual relations on persons wholive within the scope of the household; (b) the imposition of sexual relations on one person within the scope of his household with another person for commercial purposes and / or certain purposes. This form of sexual violence iscommon amongwomen because women are classified as vulnerable.

4. d. Abandonment of the Household, namely the act of neglecting people within the scope of the household, even though according to the law applicable to the person concerned or because of an agreement or agreement he is obliged to provide life, care, and care to that person. Neglectalso applies to anyone who causes economic dependence by limiting and / or prohibiting decent work inside or outside the home so that the victim is under the person's control (Ps 5 jo 9). Judging from the explanation of the article, neglect of the household is not only referred to as economic violence, butalso as complex violence. This means that not only financial neglect (not providing a living, not fulfilling the needs, etc.) but the general neglect that concerns household life (restrictions on health and education services, notgivinglove, excessivecontrol, etc.).

\section{Factors CausingDomestic Violence}

There are at least two factors that cause domesticviolence are first, internal factors due to the weak adaptability of each family member among others so that they tend to act discriminatory and exploitative towards weak family members. Secondly, external factors resulting from environmental interventions outside the family that directly or indirectly affect the attitudes of family members, manifested in exploitative attitudes towards other family members, especially with women and children. Also, Rocmat Wahab concluded that domestic violence was not just a matter of gender inequality. This often happens due to lack of communication, disharmony, economic reasons, inability to control emotions, inability to find solutions to any household problems, and intoxication due to alcohol and drugs (Wahab, 2006).

In many cases, the husband also sometimes acts violently against his wife because he feels frustrated that he cannot do something that should be his responsibility. This usually occurs in couples who are notready to marry (young marriage), the husband does not have ajob and regular income to meet the needs, and limitations freedom because you are still riding on parents/in-laws. From this condition, husband/men often seek to escape with negative things (drunk, gambling,drugs, sex) so thatitleads to an outlet for his wife in various forms, both physical, psychological, sexual, and even neglect.

In summary, it can be explained that the causes of domestic violence against women can occur in many factors. The above factors are not the only cause, but one of the triggers for domestic violence against women which continues to increase. However, regardless of whatever the cause, that all forms of violence both against women constitute grave crimes against humanity. This if left unchecked and continues continuously can lead to variousnew problems in the future. 


\section{Basic Theories of Violence}

Zastrow \& Browker 1984 in (Wahab, 2006) states that three main theories can explain the occurrence of violence, namely biological theory, frustration-aggression theory, and control theory (Wahab, 2006)

The theory explains that humans, like animals, have an aggressive instinct that has been carried from birth. Sigmund Freud theorized that humans have a desire for death that directs them to enjoy 6 acts of harming and killing others and themselves. Robert Ardery who suggested that humans have the instinct to conquer and control territory, which often leads to violent interpersonal conflict behavior. This biological theory implies that humans have an aggressive instinct from birth so that conflict behavior is considered normal as a form of defense against various pressures. This behavior can be manifested as a form of violence due to a variety of prolonged pressures (family, economic problems, etc.).

Second, the theory of frustration-aggression states that violence is a way to reduce the tension generated by frustrating situations. This theory stems from a reasonable opinion that someone who is frustrated often becomes involved in aggressive actions.

An example is the case of a husband who has been unemployed foryears and does not have asteady income to meet the needs of his family, the husband'sgreattendency isto commit violenceagainsthis wife and children due to the symptoms of frustration he experienced (even some were killed). Although everything is not like that, from many cases that occur, the effects of frustration can affect someone to commit acts of violence.

Third, control theory explains that people who are not satisfied in relating to others will be easy to commit violence. In other words, people who have good relationships with others tend to be moreable to control and control aggressive behavior. Travis Hirschi gave support to this theory. It was stated that adolescent boys who behave aggressively tend to not have good relationships with other people. The same thing happened to ex-convicts in America who were also alienated from their friends and family.

\section{Impact of domestic violence on women}

Cases of violence area serious problem. The effects al so have a wide impact. For example, disability, trauma, stress, conflicts, and even killings arise, as well as for children can disrupt the process of growth and development. In the writer's opinion, that the impact of domestic violence on women can be divided into 2 namely, short-term impacts and long-term impacts. First, short-term effects usually have direct impacts such as physical injury, disability, pregnancy, loss of work, and so on. Second, thelong-term effects usually have impacts in the future and even last a lifetime. Usually, victims experience psychological (psychiatric) disorders, loss of self-confidence, confining themselves, trauma, and fear appear until the depression.

Of the two impacts, the thing that is feared is the emergence of further violence. This means that victims who are nothandled properly are feared to become perpetrators of violence in the future as a form of venting past trauma.

Emil Sutrisminah in her research revealed, the impact of domestic violence also affects reproductive health. Women are affected by their reproductive health if they do not experience menstrual disorders while experiencing decreased libido and an inability to have an orgasm. Whereas during pregnancy, miscarriages/abortion can occur, childbirth formates and the baby dies in thewomb. Other impacts that also affect the health of the wife'sreproductive organs in the household include a change in the mindset, emotions, and family economy (Lestari, 2016). 


\section{Overview of Violence Against Womenand Children in Garut Regency in 2018)}

According to data obtained from the Department of Population Control, Family Planning, Women's Empowerment and Child Protection (DPPKBPPPA) in Garut Regency, in particular, the Women's Empowerment Sector that violence against women is recorded in the case data as presented in the following table: (Gender Selected Data for Garut Regency, 2019).

Table 1 Recapitulation of Violence Against Women and Children from 2014 to 2018

\begin{tabular}{|l|l|l|l|l|}
\hline \multirow{2}{*}{ No } & Year & Category & Child & amount \\
\hline 1 & 2014 & 46 & 51 & 97 \\
\hline 2 & 2015 & 31 & 30 & 61 \\
\hline 3 & 2016 & 37 & 104 & 141 \\
\hline 4 & 2017 & 30 & 41 & 71 \\
\hline 5 & 2018 & 17 & 43 & 60 \\
\hline amount & & 161 & 269 & 430 \\
\hline
\end{tabular}

Source: DPPKBPPPA Garut Regency 2018

Based on theabove table, itcan be stated that violence againstwomenin Garut Regency for the past five years was 430 cases, including in 2014 violence against women, 46 cases, in 201531 cases, in 2016 37 cases, in 201730 cases and 2018 there were 17 cases. This shows that the amount of violence against women has decreased from year to year. But the data recorded does not seem to describe the actual situation given the forms of violence against women still occur in Garut Regency. For more details related to Violence Against Women in 2014 to 2018 explained in the graph below:

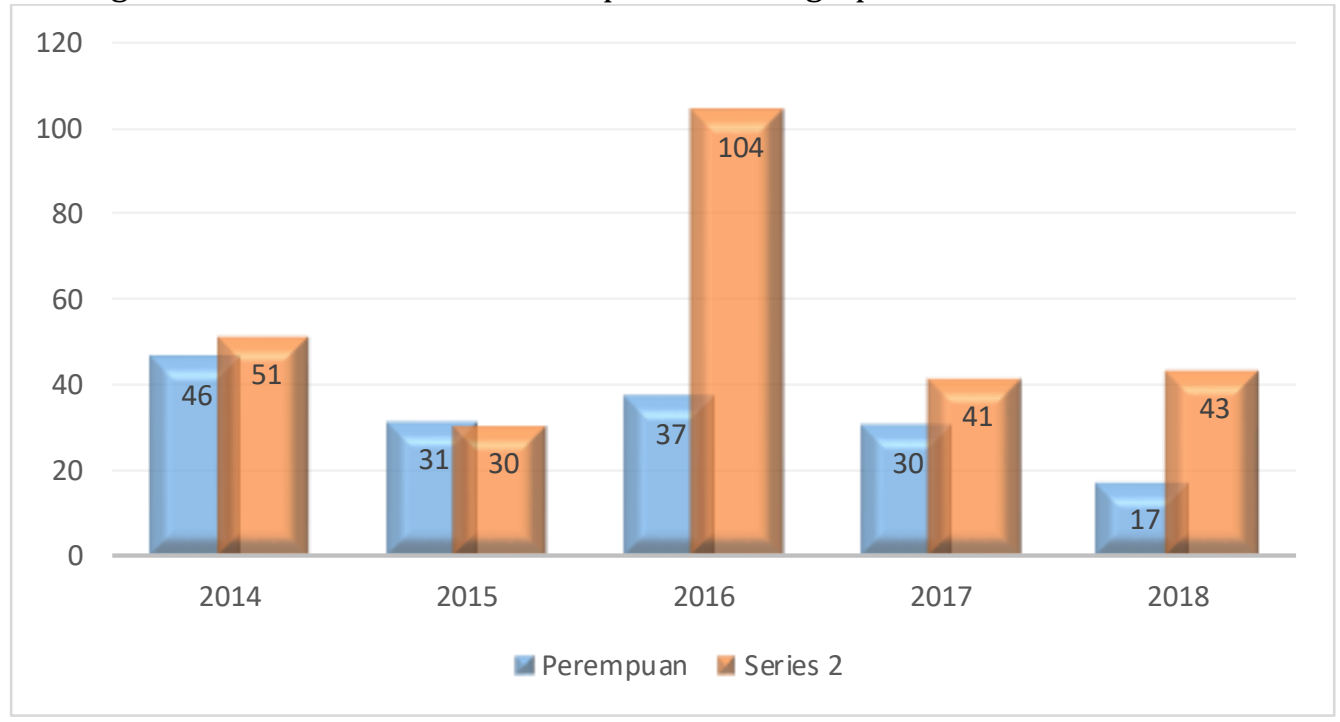

Figure 1 Recapitulation of Violence Against Women and Children from 2014 to 2018

Much physical violence, psychological violence, sexual violence, and violence against women in other forms are still not officially recorded considering that there are still many women who experience violence never report because of shame. Besides that, the perception of the community who considers this 
domestic violence problem as a private matter of the household that does not need to interfere in the household affairs of others (Chairah, 2019).

Cases of violence against women are not easily revealed cases (Santoso,2019), many cases are not reported and many cases are withdrawn by reporters who are also victims. Thisis dueto the many gender burdens that women often have to bear on their own and the strong patriarchal, religious and customary culture that places women victims of domestic violence in difficult situations to get out of the circle of violence they experience, and tends to hesitate to uncover the facts of violence. Even victims find it difficult to get support from their familiesand communities. The sinful conviction when telling of ugliness, ugliness, or husband's disgrace makes many women victims of domestic violence save in various form sof violence they experienced.

Victims are women and children who experience misery and or suffering both directly and indirectly as a result of the violence that occurred in the Garut Regency. The scope of protection of women and children from violence, as follows: 1 ). forms of violence against women and children; 2). victims' rights; 3). obligations and responsibilities; 4). organizing the protection of women and children from violence; 5). institutional; 6). cooperation and partnership; 7). monitoring and evaluation; 8). reporting; 9). funding; and 10). Penalty.

Women and children victims of violence receive the following rights: 1). the rightto respect human dignity and dignity; 2). the right to health and psychological recovery from the suffering suffered by the victim; 3). the right to determine his own decisions; 4). the right to information; 5). the right to confidentiality; 6). compensation rights; 7). the right to social rehabilitation; 8). the right to handle complaints; 9). the rightto assistance; 10). the right to obtain a free visum et repertum; and 11). the right of the victim and her family to have access to justice.

In addition to being the responsibility of the regional government, parents, guardians, and/or families legally have full responsibility for preventing all forms of violence (Kobandaha 2017), reporting violations, and protecting victims. In the case of parents, guardians, and / or family where there is no or unknown presence or for some reason they cannot carry out their obligations and responsibilities, then the obligations and responsibilities may shift to the Regional Government and other families that are carried out bystatutoryprovisions.

The Regional Government carries out activities to protect women and children from violence, which include: a. prevention; b. service; c. social rehabilitation; and D. empowerment. The victim protection is stated in the Regional Medium-Term Development Plan (RPJMD) and the Village Medium-Term Development Plan (RPJMDes). To support this protection, Garut Regency has P2TP2A and Integrated Crisis Center (PKT), Integrated Service Center (PPT), trauma recovery center (trauma center), women crisis center (women crisis center), training center, Science and Technology Information Center (PIPTEK), safe house (shelter), halfway house, or other forms.

Forms of service to victims consist of 1). services for women and children victims of violence, including a). the complaint, consultation, and counseling services; b). advisory services; c).health services; d). legal aid services; and e).social repatriation and reintegration services.2). Special services for women victims of domestic violence or trafficking in persons, including a). complaint service; b). pickup service; c). medical and psychological referral services; d). shelter services; e). advisory services and providing legal assistance; and f). social repatriation and reintegration services.

The victim is given: 1). Health services; 2). Social rehabilitation services; 3). psychological; 4). rehabilitation services; 5). Legal assistance; 6). Complaints, consultation, and counseling services; 7). Social repatriation and reintegration services. Complaints, consultation, and counseling services, including a. 
initial identification or recording of the victim; and b. approval of an action (informed consent). Health services include a. first aid to the victim by a competent officer; b. care and recovery of physical injuries aimed at recovering the physical condition of the victim by medical and paramedical personnel; and $c$. referral to health services as needed. Repatriation and social reintegration services are carried out to return victims to their families and the social environment.

Repatriation and social reintegration services are carried out by the Regional Government in coordination with a. Regency / City Government in one Province or outside the Province; and / or b. related institutions and institutions both Government and no Government. Social rehabilitation is a service provided by a companion to recover the traumatic condition of the victim. Social rehabilitation is carried out by 1). provide guidance and counseling to victims and parents of victims;2). psychological recovery of victims; 3). assistance for victims and parents in the family and community environment; and 4). provide a safe home for victims of violence who need ongoing treatment.

Specific social rehabilitation for women victims of domestic violence and trafficking in persons is carried out by 1). providing guidance and counseling; 2). psychological recovery of victims; and 3).victim assistance in the familyand community environment.

Social rehabilitation is carried out by the District Apparatus. In addition to being implemented by the District Apparatus, social rehabilitation can also be carried out by the community or social service institutions. Monitoring is carried out periodically and in an integrated manner carried out every 6 (six) months by the Regional Apparatus which organizes government affairs in the field of women's empowerment and child protection in coordination with the Regional Apparatus or other units that handle women's empowerment and child protection.

Reporting the implementation of the protection of women and children from violence,carried out by 1). P2TP2A to the Regent; 2). Subdistrict Task Force for the Protection of Women and Children at the DistrictHead; and 3). The Task Force for the Protection of Women and Children at the Village/ Kelurahan Level to the Village / Lurah Head. Reporting submitted in writing, including 1). administration; 2). finance; 3). service; and 4). the performance. Submission of a report carried out at least 3 (three) months.

\section{CONCLUSION}

Violence against women and children victims of domestic violence in GarutRegency over the past five years as many as 430 cases including 2014 violence against women, 46 cases, 31 cases in 2015, 37 cases in 2016, in 201730 cases and 2018 as many as 17 cases. This shows that the amount of violence against women has decreased from year to year. Garut Regency protects women and children who are victims of violence by fulfilling the rights of women and children victims of violence and discrimination starting from prevention efforts, social services, and rehabilitation. All protection aims to protect women and provide security in the fulfillment of their rights by providing consistent and systematic attention aimed atachieving gender equality.

\section{REFERENCES}

Bungin, B. (2007). Penelitian Kualitatif: Komunikasi, Ekonomi, Kebijakan Publik, Dan Ilmu Sosial Lainnya (Vol. 2). Kencana.

Chairah, D. (2019). Perlindungan Hukum Terhadap Perempuan Dan Anak Korban Kekerasan Dalam Rumah Tangga Di Kabupaten Sidoarjo. Al-Jinayah: Jurnal Hukum Pidana Islam, 5(1), $153-$ 175. 
Ikrom, M. (2013). Syariat Islam Dalam Perspektif Gender Dan Hak Asasi Mansia (Ham). Jurnal Supremasi Hukum, 2(1).

Jamaa, L. (2014). Perlindungan Korban Kekerasan Dalam Rumah Tangga Dalam Hukum Pidana Indonesia. Jurnal Cita Hukum, 2(2). Https://Doi.Org/10.1017/Cbo9781107415324.004

Lestari, S. (2016). Psikologi Keluarga: Penana man Nilai Dan Penanaman Konflik Dalam Keluarga. Prenada Media.

Nainggolan, M., Zahara, E., \& Saparuddin, S. (2010). Peranan Hakim Dalam Memberikan Perlindungan Hukum Terhadap Anak Korban Penyalahgunaan Narkotika (Studi Pengadilan Negeri Lubuk Pakam). Jurnal Mercatoria, 3(2), 116-132.

Santoso, A. B. (2019). Kekerasan Dalam Rumah Tangga (Kdrt) Terhadap Perempuan: Perspektif Pekerjaan Sosial. Komunitas, 10(1), 39-57.

Sholihat, L. A. (2018). Onfirmasi Empat Faktor Yang Berpengaruh Terhadap Permberdayaan Perempuan Korban Kekerasan Dalam Rumah. Jurnal Kesehatan Bakti Tunas Husada :Jurnal Ilmu Ilmu Keperawatan, Analis Kesehatan Dan Farmasi, 18(2), 185-201.

Sugiyono. (2013). Metode Penelitian Pendidikan Pendekatan Kauntitatif, Kualitatif Dan R\&D. Bandung: Alfabeta.

Surakhmad, W. (1982). Pengantar Penelitian Ilmiah Dasar. Metode Dan Teknik Bandang: Pt Trasito.

Wahab, R. (2006). Kekerasan Dalam Rumah Tangga: Perspektif Psikologis Dan Edukatif. Unisia, 29(61), 247-256. Https://Doi.Org/10.20885/Unisia.Vol29.Iss61.Art1

Wahid, E. (2018). Tinjauan Yuridis Mengenai Pemberian Perlindungan Hukum Terhadap Korban Kekerasan Dalam Rumah Tangga Di Daerah Jawa Barat (Kajian Daerah Bandung, Sukabumi, Cimahi, Indramayu, Dan Garut). Hukum Pidana Dan Pembangunan Hukum, 1(1). 